\title{
PENGEMBANGAN ASSET MANAGEMENT SYSTEM UNTUK INDUSTRI BUILDING MANAGEMENT BERBASIS CLOUD
}

\author{
Agus Waluyo ${ }^{1}$, Nur Nawaningtyas.P², Kukuh Ardy Nughroho ${ }^{3}$ \\ ${ }^{1,2,3)}$ Program Studi Magister Ilmu Komputer, Program Pascasarjana, Universitas Budi Luhur \\ Jl. Raya Ciledug, Petukangan Utara, Pesanggrahan, Jakarta Selatan 12260 \\ Telp. (021) 5853753, Fax. (021) 5869225 \\ 1'waluuyoo@gmail.com, ${ }^{2}$ tyaspusparini@yahoo.com, ${ }^{3}$ ardykukuh@gmail.com
}

\begin{abstract}
ABSTRAK
Permintaan akan properti khususnya permintaan rumah di Indonesia saat ini mengalami peningkatan yang sangat pesat. Di Indonesia sendiri setidaknya masih membutuhkan jutaan hunian yang layak.Semakin banyaknya apartemen yang tumbuh di Indonesia ini, yang membuat perkembangan bisnis properti ini menjadi kompetitif di Indonesia.

Asset management dalam apartemen merupakan faktor penting dalam dunia industri building management karena dengan asset management yang bagus akan mempengaruhi tingkat penjualan apartemen tersebut. Permasalahan yang sering terjadi di apartement yaitu : lambatnya mendapatkan data keluhan tentang kerusakan asset yang berasal dari penghuni apartemen maupun pengelola apartemen, sering terjadi penyimpangan waktu oleh engineer dalam hal melakukan pekerjaan maintenance, sulitnya dalam mengontrol biaya maintenance.

Untuk memecahkan permasalah diatas peneliti melakukan tinjauan pustaka, pengumpulan data, analisis, merancang model, membangun prototype dan di lakukan pengujian dengan metode user acceptance test.Hasil dari penelitian ini adalah model asset management system dan prototype asset management system yang sesuai dengan requirment yang dilakukan sebelumnya.Penelitian ini telah di uji menggunakan metode user acceptance test, dan hasil pengujian tersebut mendapatkan presentase $80.61 \%$, yang artinya system ini dapat diterima dan sesuai dengan yang diharapkan.Dalam penelitian ini, peneliti memilih Apartemen Oasis sebagai objek penelitian karena Apartemen tersebut merupakan salah satu Apartemen terbesar di Jakarta
\end{abstract}

Kata Kunci : asset manajemen, cloud, asset management system,prototype, user acceptance test

\section{PENDAHULUAN}

Asosiasi Real Estate Indoneia atau disingkat (REI) mengungkapkan jika pertumbuhan bisnis properti di Indonesia, masih bisa terus mengalami peningkatan, bahkan peningkatan ini bisa mencapai 20\%-30\% dalam setahun (http://www.rei.or.id). Permintaan akan properti khususnya permintaan rumah di Indonesia saat ini mengalamin peningkatan yang sangat pesat. Di Indonesia sendiri setidaknya masih membutuhkan jutaan hunian yang layak.Bisnis properti yang ada diIndonesia itu banyak macamnya, antara lain : ruko (rumah toko), rukan (rumah kantor), apartemen, rumah hunian dan lain-lain. Dalam penelitian ini memilih apartemen sebagai objek penelitian. Semakin banyaknya apartemen yang tumbuh di Indonesia ini yang membuat perkembangan bisnis properti menjadi kompetitif di Indonesia (http://www.neraca.co.id). Bisnis properti khususnya rumah hunian apartemen yang awalnya dipandang sebelah mata kini justru menjadi primadona dimana angka penjualan tertinggi properti di Indonesia, didominasi oleh rumah hunian apartemen. Banyaknya masyarakat yang memilih untuk tinggal di sebuah apartemen, khususnya masyarakat kota disebabkan karena mulai macet jalan raya, jarak rumah dengan tempat bekerja yang jauh, semakin banyak pembangunan apartemen yang menyebabkan harga bersaing dan lain-lain. Sehingga banyak masyarakat yang ingin tinggal di apartemen.

Perkembangan tekhnology mengubah trend dalam mengelola apartemen, salah satunya dalam memelihara asset management. Dalam penelitian ini, peneliti memelih cloud computing dalam pengembangan asset management system. Cloud adalah adalah sebuah model yang memungkinkan untuk ubiquitous (diamanapun dan kapanpun), nyaman, on-demand akses jaringan ke sumber daya komputasi (contoh: jaringan, server, storage, aplikasi, dan layanan) yang dapat dengan cepat dirilis atau ditambahkan (Peter Mell dan Timothy Grance, 2012). Fungsi dari Could itu sendiri yaitu menjalankan program atau aplikasi melalui komputer-computer yang terhubung pada waktu yang sama. Teknologi sistem cloud ini merupakan sebuah teknologi yang menjadikan internet sebagai pusat server untuk mengelola data dan juga aplikasi pengguna. Pengguna dapat menjalankan program tanpa instalasi dan mengakses data pribadi mereka melalui komputer dengan akses internet. Cloud Computing digunakan dikarenakan dari segi pembiayaan lebih hemat, dapat diakses kapanpun dan dimanapun sehingga memudahkan bagi pengguna untuk mencari atau menganalisa data selama memiliki koneksi internet.

Keberhasilan industri properti terutama apartemen tergantung layak atau tidaknya asset management yang ada 
pada apartement tersebut, karena dengan asset management yang bagus akan mempengaruhi tingkat penjualan apartemen tersebut. Dalam mengelola asset managemet di apartemen melibatkan engineer dalam maintenanceasset, divisifinance dalam mengelola keuangan, tenan relationship untuk mencatat keluhan yang berasal dari penghuni maupun pengelola.adapun permasalahan yang sering terjadi di apartement yaitu : lambatnya mendapatkan data keluhan tentang kerusakan asset yang berasal dari penghuni apartemen maupun pengelola apartemen, sering terjadi penyimpangan waktu oleh engineer dalam hal melakukan pekerjaan maintenance, sulitnya dalam mengontrol biaya maintenance.

Diharapkan dengan adanya pengembangan menggunakan sistem cloud di apartemen dapat membantu pihak management untuk lebih cepat merespon keluhan dari para penghuni apartemen. Selain itu dengan adanya perancangan pengembangan sistem ini diharapkan proses pelaporan kinerja perusahaan dapat berlangsung lebih cepat dan akurat. Sehingga membantu manajer dalam memperoleh informasi perkembangan transaksi yang aktual dan membantu menganalisa perkembangan transaksi yang terjadi pada perusahaan tersebut

\section{LANDASAN TEORI}

\section{A. Pengertian Cloud Computing}

Menurut Peter Mell dan Timothy Grance (2012) definisi Cloud Computing adalah sebuah model yang memungkinkan untuk ubiquitous (diamanapun dan kapanpun), nyaman, nndemand akses jaringan ke sumber daya komputasi (contoh: jaringan, server, storage, aplikasi, dan layanan) yang dapat dengan cepat dirilis atau ditambahkan. Cloud Computing sebagai suatu layanan teknologi informasi yang dapat dimanfaatkan oleh pengguna dengan berbasis jaringan/internet. Dimana suatu sumber daya, perangkat lunak, informasi dan aplikasi disediakan untuk digunakan oleh komputer lain yang membutuhkan. Cloud computing mempunyai dua kata "Cloud" dan "Computing". Cloud yang berarti internet itu sendiri dan Computing adalah proses komputasi[1].

Konsep cloud computing biasanya dianggap sebagai internet. Karena internet sendiri digambarkan sebagai awan (cloud) besar (biasanya dalam skema jaringan, internet dilambangkan sebagai awan) yang berisi sekumpulan komputer yang saling terhubung. Cloud computing datang sebagai sebuah evolusi yang mengacu pada konvergensi teknologi dan aplikasi lebih dinamis. Dimana terdapat perubahan besar memiliki implikasi yang menyentuh hampir setiap aspek komputasi. Untuk end user, komputasi awan menyediakan sarana untuk meningkatkan layanan baru atau mengalokasikan sumber daya komputasi lebih cepat.

\section{B. Pengertian Asset Management}

Sebuah asset dapat berwujud (tangible) dan tidak berwujud (intangible). Setiap asset yang dimiliki haruslah dikelola dengan efektif dan efisien sehingga asset tersebut dapat memberikan manfaat. Mungkin istilah manajemen asset jarang didengar oleh orang banyak dikarenakan orang lebih lebih sering mendengar kata yang terpisah yaitu manajemen dan asset. Manajemen sendiri meliputi dari 4 (empat) unsur diantaranya planning, organizing, leading dan controlling, dan untuk kata asset pada umumnya berarti kekayaan. Kekayaan yang berwujud bisa seperti tanah, gedung, peralatan dan mesin yang pada umumnya berorientasi pada pelayanan public. Dan untuk kekayaan tidak berwujud seperti hak kekayaan intelektual, hak cipta, hak paten dan lain - lain.

Menurut Sugiama (2013) Manajemen asset adalah ilmu dan seni untuk memandu pengelolaan kekayaan yang mencakup prses merencanakan kebutuhan asset, mendapatkan, menginventarisasi, melakukan legal audit, menilai, mengoperasikan, memeliharaan, membaharukan atau menghapuskan hingga mengalihkan asset secara efektif dan efisien. Selain itu manajemen asset merupakan suatu proses sistematis yang mempertahankan, meng-upgrade, dan mengoperasikan asset dengan cara yang paling hemat biaya melalui penciptaan, akuisisi, operasi, pemeliharaan, rehabilitasi dna penghapusan asset yang terkait dengan (1) mengidentifikasikan apa saja yang dibutuhkan asset, (2) mengidentifikasi kebutuhan dana, (3) memperoleh asset, (4) menyediakan sistem dukungan logistic dan pemeliharaan untuk asset, (5) menghapus atau memperbaharui asset sehingga efektif dan efisien serta dapat memenuhi tujuan[2].

Manajemen asset bertujuan untuk pengambilan keputusan yang tepat agar asset yang dikelola berfungsi secara efektif dan efisien. Efektif adalah pencapaian hasil yang sesuai dengan tujuan yang telah ditetapkan sebelumnya. Efektif di dalam pengelolaan asset berarti asset yang dikelola dapat mencapai tujuan yang diharapkan. Dan untuk efektivitas berarti derajat keberhasilan yang dapat dicapai berdasarkan tujuan yang telah ditetapkan. Dengan kata lain sebuah efektivitas merupakan suatu ukuran atau tolak ukur yang menunjukkan tinggi - rendahnya target yang telah dicapai. Pencapaian target tinggi berarti efektifitas makin tinggi, mampu mencapai tujuan atau sasaran yang telah ditetapkan. Sedangkan untuk efisien berarti menggunakan sumber daya serendah mungkin untuk mendapat hasil (output) yang tinggi. Di dalam manajemen asset, efisiensi yang senantiasa melekat dalam setiap tahap pengelolaan asset terutama upaya mencapai efisiensi yang tinggi dalam menggunakan waktu, tenaga dan biaya.

\section{Pengertian Industri Building Management}

Industri adalah suatu usaha atau kegiatan pengolahan bahan mentah atau barang setengah jadi menjadi barang jadi barang jadi yang memiliki nilai tambah untuk mendapatkan keuntungan. Sedangkan building management merupakan pekerjaan pengelolaan rangkaian kegiatan untuk membuat persiapan sejak awal sebelum gedung beroperasi dan untuk mencapai tujuan utama dari pengelolaan gedung yang dikoordinir oleh seorang building manager. Building Management atau pengelolaan gedung adalah suatu kegiatan yang tidak mudah, pengelola harus memiliki multi talenta dan multi skills dan knowledge, dimana banyak dimensi yang harus dimiliki oleh pengelola, sehubungan dengan begitu kompleksnya permasalahan yang dihadapi.

Dari definisi diatas, industri buildingmanagement di dalam penelitian ini adalah suata usaha atau kegiatan yang mengelola gedung dalam kegiatannya untuk mendapatkan 
keuntungan. Dalam penelitian ini jenis dari industry building management bermacam-macam, mulai dari pengeloaan rumah, toko,apartemen, dan lain sebagianya. Tugas dari building management seperti : bagaimana mengelola fisik bangunan gedung, bagaimana cara yang baik dan tepat untuk memilih vendor (pemasok atau supplier) dan bagaimana cara mengawasi pekerjaannya, bagaimana membuat customer (tenant) merasa aman dan nyaman, Customer (tenant) juga merasa puas atas pelayanan yang diberikan, sehingga gedung selalu memiliki tingkat hunian yang maksimal dan 1 hal yang harus diperhatikan yaitu dengan tingkat hunian yang tinggi, maka biaya untuk investasi gedung beserta fasilitasnya bisa cepat kembali sesuai dengan apa yang telah direncanakan.

\section{User Acceptance Testing}

Menurut (Perry,2007), user acceptance testing merupakan pengujian yang dilakukan end user dimana user tersebut adalah staff karyawan perusahaan yang langsung berinteraksi dengan system dan dilakukan verifikasi apakah fungsi-fungsi yang ada telah berjalan sesuai dengan kebutuhan/fungsinya[3].

Menurut (Lewis, 2003), setelah dilakukan system testing, acceptance testing menyatakan bahwa system software memenuhi persyaratan. Acceptance testing merupakan pengujian black box untuk menguji system terhadap spesifikasinya. Penggunaan terakhir bertanggung jawab untuk memastikan semua fungsionalitas yang relevan telah diuji[4].

User acceptance testing biasanya berusaha menunjukkan bahwa system telah memenuhi persyaratan-persyaratan tertentu (Black, 2002). Pada pengembangan software dan hardware komersial, acceptance test biasanya disebut juga "alpha test" (dilakukan oleh pengguna in-house) dan "beta test" (dilakukan oleh pengguna yang sedang menggunakan atau akan menggunakan system tersebut). Alpha dan beta test biasanya juga menunjukkan bahwa produk sudah siap untuk di jual atau di pasarkan. Acceptance testing mencakup data, environment dan scenario yang sama atau hamper sama pada saat live yang biasanya berfokus pada scenario penggunaan produk tertentu[5].

\section{RANCANGAN SISTEM DAN APLIKASI}

\subsection{Metode Penelitian}

Penelitian tentang pengembangan asset management system berbasis cloud untuk industry building management ini menggunakan metode penelitian deskriptif kualitatif dengan studi kasus, yang bertujuan untuk mendapatkan gambaran yang lebih mendalam dan lengkap dari objek yang akan diteliti. Penelitian deskriptif kualitatif adalah suatu prosedur penelitian yang menggunakan data deskriptif berupa kata-kata tertulis atau lisan dari seseorang atau pelaku yang dapat diamati. Penelitian deskriptif kualitatif lebih mengutamakan sebuah proses yang dilakukan daripada hasil akhirnya. Hal ini disebabkan karena hubungan antar setiap bagian yang diteliti akan jauh lebih jelas apabila diamati dalam sebuah proses.

\subsection{MetodePemilihanSampel}

Metode pengambilan atau pemilihan sampel dalam penelitian ini adalah dengan menggunakan teknik judgement atau purpose sampling. Teknik ini merupakan salah satu prosedur Sampling Non-Probabilita. Pengambilan sampel dengan purposive sampling merupakan teknik pengambilan sampling dengan cara mengambil responden yang terpilih betul oleh peneliti menurut ciri-ciri spesifik yang di miliki karena dengan pemilihan sampel yang sesuai kebutuhan akan mempermudah dalam hal menganalisa kebutuhan pengguna.

Adapun kriteria pemilihan responden sebagai sampel penelitian ini adalah:

1. Memiliki tugas dan tanggung jawab sebagai manajer atau pimpinan di apartemen.

2. Memiliki pengalaman pekerjaan dalam hal mengelola keluhan aset yang ada diapartemen.

3. Memiliki kemampuan dalam hal melakukan maintence aset yang ada diapartemen.

4. Memiliki pengalaman dalam hal pengelolaan keuangan yang ada di apartemen

\subsection{Langkah - Langkah Penelitian}

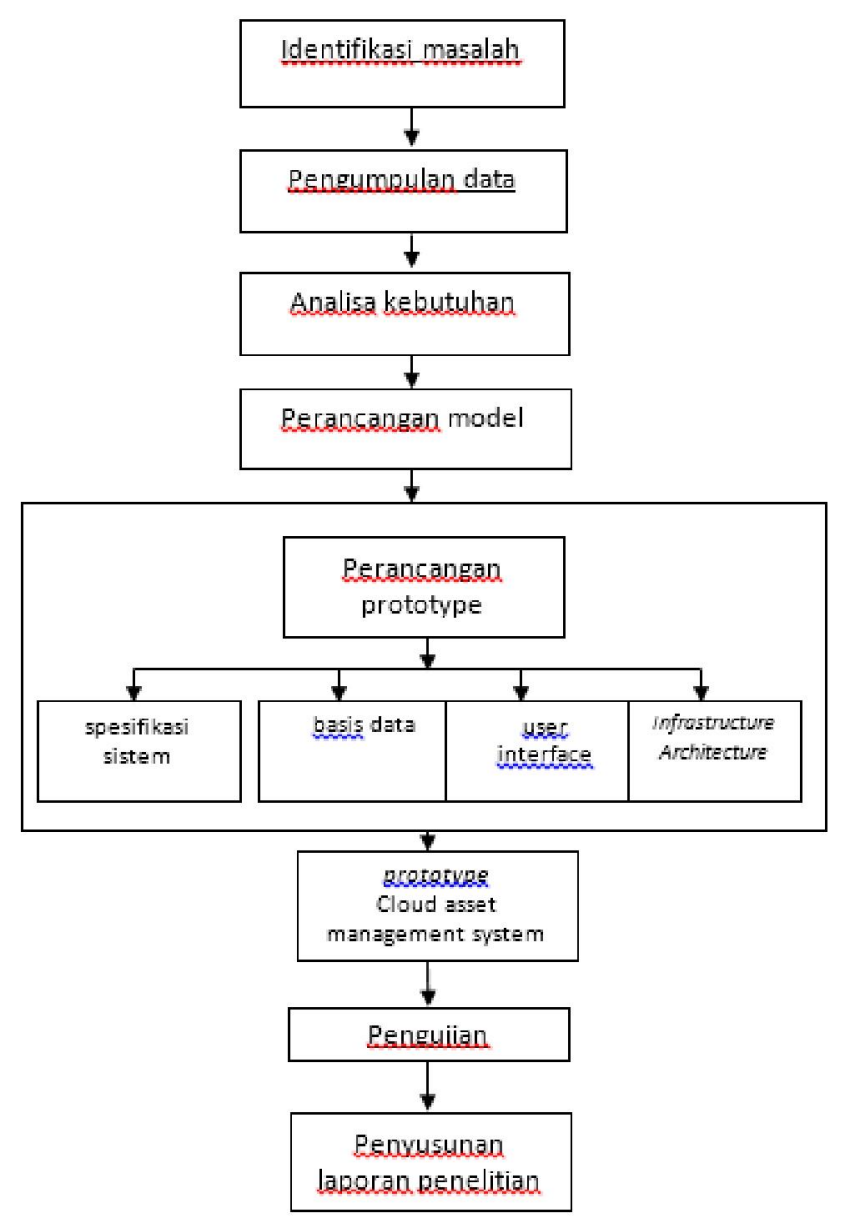

Gambar 1: Langkah-langkah Penelitian

\subsection{Teknik Pengujian Sistem}

Tahap pengujian ini dilakukan dengan menggunakan metode user acceptance test Dengan metode ini diharapkan dapat memperoleh hasil yang baik dan akurat dari para responden. Data yang diperoleh merupakan factor penentu perangkat lunak diterima atau tidak oleh user. Pengujian 
merupakan proses pemeriksaan atau evaluasi system atau komponen system untuk memverifikasi apakah system sudah sesuai dengan kebutuhan user, di mana akan diidentifikasi perbedaan-perbedaan antara hasil yang diharapkan dengan hasil yang terjadi.

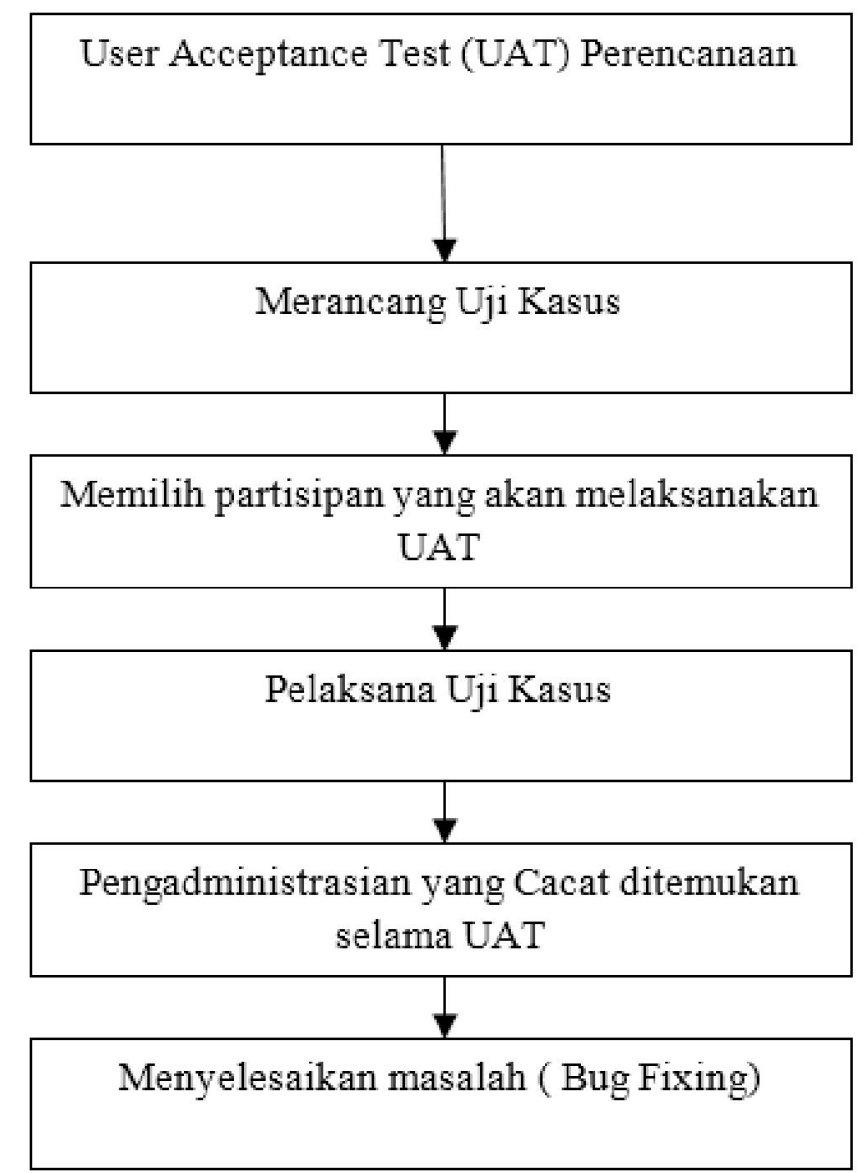

Gambar 2 : struktur pengujian prototipe

\subsection{Analisis System Saat ini}

Pada tahap analisis system saat ini di lakukan sebuah analisa terhadap kondisi insfratruktur,proses atau kegiatan yang di lakukan pada apartemen oasis. hasil dari analisis ini akan menentukan strategi yang akan dilakukan selanjutnya dalam mengambangkan assetmanagementsystem berbasis cloud.

Dalam melakukan analisa, proses yang terpenting adalah bagaimana proses jika terjadi keluhan terhadap asset yang ada di apartemen, cara engineer dalam melakukan proses maintenance dan bagaiman cara melakukan pembiayaan jika dalam melakukan perbaikan dibutuhkan biaya.Dari hasil pengamatan dan analisa proses bisnis yang terjadi saat ini di mulai dari tenant atau penghuni melakukan pelaporan kepada tenant relation jika ada kerusakan aset, tenant relation akan mencatat laporan tersebut. Dari laporan tersebut maka, tenant relation akan memberitahukan kepada engineer jika ada aset yang rusak. Engineer akan melakukan perbaikan dan akan memberitahukan proses pengerjaan jika sudah selesai diperbaiki.jika dalam proses pengerjaan terdapat biaya yang dibutuhkan, maka bagian finance akan mengeluarkan uang untuk keperluan maintenance dan mencatatnya sebagai biaya maintenance.

\subsection{Perancangan Model Asseet Management System Berbasis Cloud}

Dari hasil analisi proses bisnis yang ada sekarang, maka dapat dibuatkan model assetmanagementsystem berbasis cloud sebagai berikut :

1. Tenant melaporkan keluhan aset kepada tenant relation melalu sms, whataps maupun telepon

2. Tenant memberikan balasan kepada tenant yang melaporkan tentang kerusakan aset

3. Tenant relation menginput data keluhan tersebut ke dalam sistem

4. Sistem akan memberikan notifikasi kepada engineer

5. Engineer memberikan upgrade tentang progress maintenance

6. Engineer membuat pengajuan biaya, jika dalam proses pengerjaan memerlukan biaya.

7. Finance input data biaya ke dalam sistem

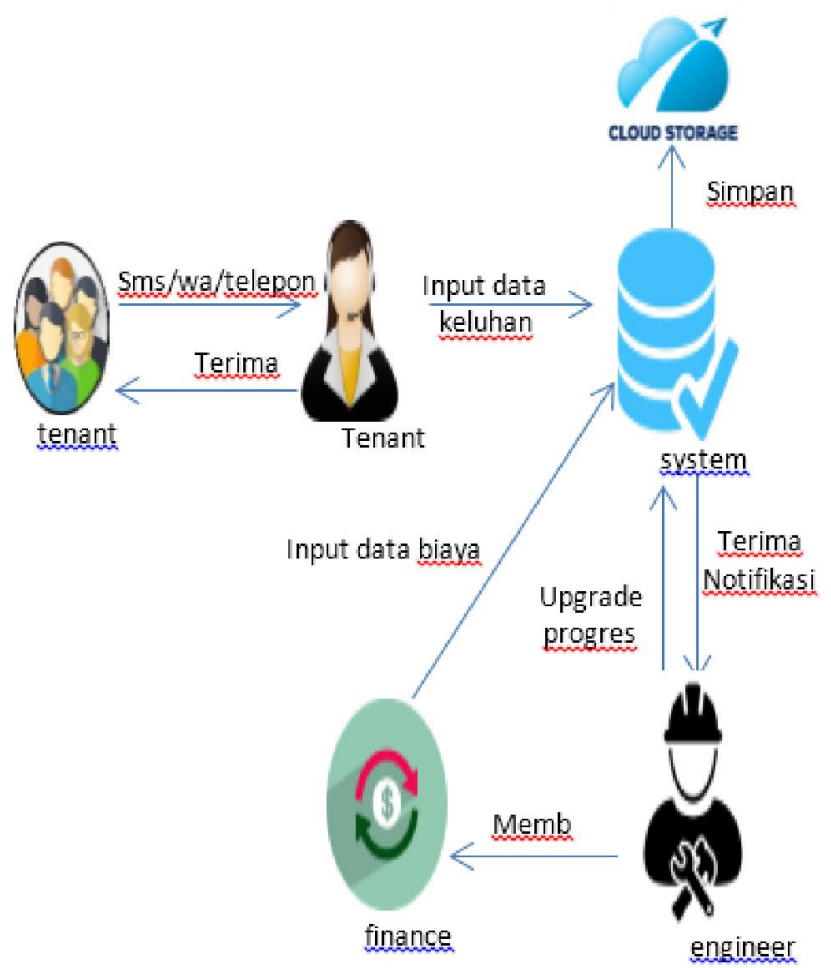

Gambar 3 : Model Asseet Management System

\subsection{Analisa Kebutuhan}

A. Kebutuhan Fungsional

Beberapa kebutuhan fungsional yang akan diimplementasikan dalam pengambangan asset management system berbasis cloud nanti adalah sebagai berikut:

1. Pendataan keluhan

Sistem akan mendata jika terjadi keluhan tentang kerusakan asset, baik yang berasal dari penghuni maupun non penghuni. 
2. Monitoring kinerja engineer

System dapat memonitoring kinerja engineer mulai dari proses sampai pekerjaan tersebut selesai.

3. Mencatat biaya maintenance

System dapat mencatat biaya yang dibutuhkan dalam proses maintenance asset yang dilakukan oleh engineer.

4. Laporan

System dapat membuat laporan tentang keluhan asset, kinerja enginer dan biaya maintenance.

B. Kebutuhan Non Fungsional

Setelah kebutuhan fungsional sudah diketahui, makan selanjutnya adalah kebutuhan non fungsional,diantaranya adalah :

1. kebutuhan operasional

system yang dibangun dapat digunakan dan diakses selama 24 jam setiap harinya.

2. Kebutuhan keamanan

Pengguna yang mengoperaikan system nanti adalah pengguna yang memiliki hak akses yang diberikan oleh administrator.

3. Kebutuhan penyimpanan data

System diharapkan dapat menyimpan data dalam jumlah yang besar dan dapat diakses oleh banyak user dalam waktu bersamaan.

4. Kebutuhan Kemudahan Pengguna.

System yang dibangun diharapkan mudah untuk dipelajari dan mudah untuk digunakan (user friendly)

C. Kebutuhan pengguna

Pengguna asset management system ini adalah tenant relation, engineer, finance. Dibawah ini merupakan pengguna dan fungsi yang dibutuhkan oleh masing-masing pengguna dalam pengoperasian asset management system :

\section{Tenantrelation}

Fungsi yang dibutuhkan oleh tenant relation dalam assetmanagementsystem berbasis cloud ini adalah :

a. mengelola data penghuni

b. menerima data keluhan

c. mengelola data keluhan

2. Engineer

Fungsi yang dibutuhkan oleh engineer dalam assetmanagement system ini adalah :

a. menerima data keluhan asset yang berasal dari tenant relation

b. mengerjakan asset management yang rusak

3. finance

Fungsi yang dibutuhkan oleh finance dalam mengelola asset management system ini adalah :

a. mengelola keuangan yang berkaitan dengan biaya maintenanceasset

b. menyetujui atau menolak pengajuan yang dilakukan oleh engineer

\section{PENUTUP}

\section{A. Kesimpulan}

Dari pembahasan pada bab-bab sebelumnya dapat disimpulkan beberapa hal sebagai berikut :

1. Pengembangan asset management system berbasis cloud yang dibangun dapat meningkatkan kecepatan dan efisiensi dalam melakukan pendataan keluhan tentang kerusakan asset.

2. Pengembangan asset management system berbasis cloud yang dibangun dapat untuk pengontrolan Kinerja engineer dalam melakukan maintenance sering di manipulasi.

3. Pengembangan asset management system berbasis cloud yang dibangun dapat untuk mengontrol biaya maintenance asset.

\section{B. Saran}

1. Dalam melakuan user acceptance tets, perlu di lakukan dalam waktu yang sama dengan beberapa user untuk melihat kemampuan pengembangan cloud asset management system yang dibangun.

2. Perlu adanya pelatihan pengguna asset management system berbasis cloud kususnya pengguna baru supaya tidak terjadi masalah dalam pengoperasiannya.

3. Diharapkan membackup database setiap minggunya agar memperkecil resiko hal yang tidak diinginkan.

\section{DAFTAR PUSTAKA}

[1] Peter Mell, dan Timothy Grance. 2012. The NIST Definition of Cloud Computing. Gaithersburg.

[2] Sugiama,A.Gima.2013.Manajemen Aset Pariwisata. Bandung:Guardaya Intimart

[3] Perry, 2007.Organisational Management and Information System.Elsevier dan Technology Books, 2006

[4] Lewis,W.,Agarwal,R.,Sambamurthy.V.(2003).Source $\mathrm{s}$ of Influence on Beliefs about Information Technology Use : An Emprical Study of knowledge Workers.MIS Quarterly,Vol.27, No.4,hal.657-678

[5] Black NJ, Lockett A, Ennew C, Winklhofer H, McKechine S (2002). Modelling Consumer Choice of Distribution Channels: an illustration from financial services.Int J.Bank Mark.20 (4) :161-173 